\title{
AKUNTABILITAS DAN TRANSPARANSI PENGELOLAAN DANA DESA DI DESA TELLUMPANUAE KABUPATEN MAROS
}

\author{
Sri Wahyuni Nur ${ }^{1}$ \\ Institut Agama Islam Negeri Parepare ${ }^{1}$ \\ Email Korespondensi: sriwahyuninur20@gmail.com
}

\begin{abstract}
Abstrak: Dana desa yang di kelola oleh Pemerintah Desa ditujukan untuk membiayai program pemerintah desa dalam pelaksanaan kegiatan pemerintahan. Dana desa yang diberikan kepada pemerintah desa harus dikelola dengan baik dan tepat sasaran dimana dalam pengelolaannya harus mengedepankan akuntabilitas dan transparansi khususnya kepada masyarakat. Akuntabilitas merupakan suatu pertanggungjawaban pemerintah untuk melaporkan dan menyajikan kegiatan-kegiatan yang telah dilaksanakan kepada masyarakat. Pertanggungjawaban tersebut dilakukan agar pemerintah dapat transparan dengan komitmen yang telah terbentuk dalam pelaksanaannya. Penelitian ini bertujuan untuk menilai akuntabilitas dan transparansi pemerintah desa dalam pengelolaan Dana Desa di desa Tellumpanuae, Kecamatan Mallawa, Kabupaten Maros. Penelitian ini menggunakan metode deskriptif kualitatif melalui studi lapangan yang dibagi menjadi tiga tahap yaitu persiapan, pelaksanaan, dan rencana keberlanjutan. Teknik pengumpulan data yang digunakan berupa wawancara dengan teknik semi terstruktur. Wawancara dilakukan dengan pihak pemerintah desa setempat dan tokoh masyarakat yang termasuk dalam Badan Permusyawaratan Desa (BPD) keseluruhannya berjumlah 10 orang informan. Hasil penelitian menunjukkan bahwa sebagai wujud akuntabilitas Pemerintah Desa Tellumpanuae telah melakukan prosedur pengelolaan dan pertanggungjawaban Dana Desa sesuai dengan Permendagri No. 113 Tahun 2014. Sebagai wujud transaparansi Pemerintah Desa Tellumpanae adanya papan informasi yang berisi program yang telah direalisasikan beserta anggarannya. Meskipun pengelolaan dana desa yang dilakukan oleh pemerintah desa sangat baik, tetapi pemahaman masyarakat mengenai kebijakan dana desa masih rendah.
\end{abstract}

Kata Kunci: Akuntabilitas, Transparansi, Dana Desa

Akuntansi pemerintahan tidak hanya diterapkan di pemerintah pusat, namun juga di tingkat daerah sampai di wilayah pedesaan, yang semuanya itu membutuhkan pertanggungjawaban di setiap anggaran dan kegiatan yang dilaksanakan. Dalam perkembangannya, kini desa telah berkembang menjadi berbagai bentuk yang harus diberdayakan sehingga menjadi desa yang mandiri, maju, dan kuat untuk mencapai masyarakat yang adil, makmur, dan sejahtera. Desa memiliki wewenang untuk mengatur sendiri kawasannya sesuai kemampuan dan potensi yang dimiliki masyarakatnya agar tercapai kesejahteraan dan pemerataan kemampuan ekonomi.

Alokasi Dana Desa pada Peraturan Pemerintah Republik Indonesia pasal 1 nomor 47 tahun 2015 adalah dana perimbangan yang diterima 
kabupaten/kota dalam anggaran pendapatan dan belanja daerah kabupaten/kota setelah dikurangi Dana Alokasi Khusus. Pelaksanaan Alokasi Dana Desa ini digunakan untuk program-program fisik dan non fisik yang berhubungan dengan Perkembangan Desa. Peraturan Daerah Kabupaten Maros Nomor 01 Tahun 2006 Pasal 5 disebutkan bahwa Dana Desa dialokasikan oleh Pemerintah untuk Desa. Rincian dana setiap Desa dialokasikan secara merata dan berkeadilan berdasarkan Alokasi Dasar dan Alokasi Formula dengan memperhatikan beberapa variabel diantaranya kemiskinan, pendidikan dasar, kesehatan, keterjangkauan, jumlah penduduk, luas wilayah, jumlah dusun, potensi ekonomi, dan partisipasi masyarakat.

Pengelolaan dan pelaksanaan kegiatan Pemerintahan Desa sebagai pemerintahan yang baik (Good Governance), perlu adanya suatu aspek tata pemerintahan, salah satu unsur utama dari good government adalah Akuntabilitas. Menurut Waluyo dalam Astuty dan Fanida (2013) akuntabilitas meliputi pemberian informasi keuangan kepada masyarakat dan pengguna lainnya sehingga memungkinkan bagi mereka untuk menilai pertanggungjawaban pemerintah atas semua aktifitas yang dilakukan. Akuntabilitas merupakan bentuk tanggungjawab pelaksanaan misi organisasi dalam mencapai tujuan yang ditetapkan melalui media pertanggungjawaban yang dilaksanakan secara periodik. Akuntabilitas pemerintahan dianggap sangat diperlukan sebagai penunjang penerapan otonomi Desa agar berjalan dengan baik (Putriyanti, 2012).

Selain Akuntabilitas untuk pelaksanaan Pemerintahan yang baik juga diperlukan adanya unsur Transparansi. Menurut Dwiyanto (2006) transparansi adalah sebagai penyedia informasi tentang pemerintahan publik dan dijaminnya kemudahan didalam memeproleh informasi yang akurat dan memadai. Alokasi Dana Desa yang dikucurkan Pemerintah Pusat maupun dari APBD harus diumumkan secara transparan kepada publik, khususnya warga desa setempat. hal tersebut untuk menghindari terjadinya penyelewengan dana, kecurigaan publik, dan supaya pembangunan di desa dapat berlangsung secara kondusif.

Sulistiyani (2004) menyatakan bahwa Transparansi dan Akuntabilitas adalah dua kata kunci dalam penyelenggaraan Pemerintahan maupun penyelenggaraan perusahaan yang baik (Good Governance). Transparansi ditandai oleh apakah kebijakan, regulasi, program, anggaran dan kegiatan pemerintah terbuka pada publik. Asas pengelolaan keuangan daerah dalam Pemendagri No. 113 tahun 2014 dimana keuangan desa dikelola berdasarkan asas-asas transparan, akuntabel, partisipatif serta dilakukan dengan tertib disiplin anggaran.

Penelitian ini terkait dengan Teori agensi, dimana teori agensi merupakan konsep yang menjelaskan hubungan kontraktual antara principals dan agents. Pihak principals adalah pihak yang memberikan mandat kepada pihak lain, yaitu agent, untuk melakukan semua kegiatan atas nama principals dalam kapasitasnya sebagai pengambil keputusan, (Jensen dan Smith, 1984). Agar agen dapat mengerjakan tugas-tugasnya, 
prinsipal 141 mendelegasikan wewenang pengambilan keputusan sampai batas waktu tertentu kepada agen (Ross, 1973).

Pada organisasi sektor publik yang dimaksud dengan principal merupakan rakyat dan agen adalah pemerintah dalam hal ini adalah kepala desa dan aparat desa lainnya. Ismail dkk (2016) menjelaskan bahwa "akuntabilitas dan transparansi adalah kewajiban pemegang amanah/agent/kepala desa dan aparatnnya untuk memberikan pertangungjawaban, menyajikan, melaporkan, dan mengungkapkan segala aktivitas dan kegiatan yang menjadi tanggung jawabnya kepada pihak pemberi amanah (principal) yang memiliki hak dan kewenangan untuk meminta pertanggungjawaban tersebut". Kepala desa dan aparat desa lainnya bertanggungjawab atas pelaksanaan kebijakan dan pengelolaan sumber daya yang dipercayakan oleh masyarakat desa. Kepala desa dan aparat desa lainnya juga harus memberikan informasi keuangan yang terbuka dan jujur kepada masyarakat berdasarkan pertimbangan bahwa masyarakat memiliki hak untuk mengetahui secara terbuka dan menyeluruh atas pertanggungjawaban pemerintah dalam pengelolaan sumber daya yang dipercayakan kepadanya dan ketaatan pada peraturan perundangundangan.

Adapun desa yang menjadi objek penelitian ini adalah Desa Tellumpanuae. Desa Tellumpanuae secara administratif berada di Kecamatan Mallawa, Kabupaten Maros, Provinsi Sulawesi Selatan. Secara geografis, desa Tellumpanuae termasuk dalam daerah dataran yang relatif tinggi dengan kontur wilayah yang berupa bukit-bukit. Hal ini didasarkan pada letaknya yang dikelilingi oleh pegunungan disekelilingnya. Keadaan ini secara nyata menguntungkan bagi masyarakat desa Tellumpanuae sendiri, karena sebagian besar penduduknya bermata pencaharian sebagai petani, selain itu keadaan ini juga memberikan potensi yang cukup besar bagi desa ini karena dapat dijadikan sebagai daerah tujuan wisata. Iklim yang cukup bersahabat bagi bidang pertanian dan perkebunan membuat desa Tellumpanuae sangat berpotensi untuk dijadikan kawasan agrowisata. Ditambah lagi dengan curah hujan yang tinggi membuat tanaman sayur dan buah dapat tumbuh dengan baik dan subur.

Permasalahan yang ditemui peneliti pada saat observasi awal yaitu di Desa Tellumpanuae dalam pengelolaan Alokasi Dana Desa dari aspek Akuntabilitas, dimana permasalahan yang ada adalah masih rendahnya kapasitas aparatur Pemerintahan Desa, dalam penguasaan teknologi, manajemen dan pelayanan kepada masyarakat. Hal ini disebabkan karena kurangnya sosialisasi dan pelatihan berbasis IPTEKS pada Pemerintah Desa, selain itu minimnya akses informasi dan pengetahuan bagi masyarakat desa menjadi salah satu penyebab lemahnya kapasitas desa, baik pada masyarakat maupun perangkat desa.

Sedangkan permasalahan dari aspek transparansi adalah masih belum dijalankan dengan baik, dimana tidak ada informasi di papan pengumuman atau papan informasi mengenai jumlah pengeluaran 
maupun pemasukan dalam menjalankan kegiatan Alokasi Dana Desa. Hal ini disebabkan karena pemerintah desa kurang responsif dalam hal keterbukaan dalam proses perencanaan, pelaksanaan, dan penyusunan anggaran daerah. Sementara prinsip transparansi memberikan arti bahwa anggota masyarakat memiliki hak dan akses yang sama untuk mengetahui proses anggaran karena menyangkut aspirasi dan kepentingan masyarakat, terutama dalam pemenuhan kebutuhan hidup masyarakat. Transparansi mutlak dilakukan oleh pemerintah desa agar kepercayaan publik dan warga akan penggunaan dana desa menguat.

Masalah lainnya yang sering dihadapi seperti yang disampaikan oleh tokoh masyarakat adalah masih rendahnya partisipasi masyarakat. Hal ini disebabkan karena dominasi kepala desa dan minat masyarakat yang kurang dalam pelaksanaan program alokasi dana desa. Masih rendahnya partisipasi masyarakat dalam pengelolaan Alokasi Dana Desa sehingga program-program yang telah direncanakan oleh Pemerintah Desa tidak dapat berjalan sesuai dengan perencanaan yang telah dibuat.

Penelitian ini mengacu pada penelitian sebelumnya yang dilakukan oleh Wiradarma (2017) yang meneliti tentang Analisis Transparansi dan Akuntabilitas Pelaporan Alokasi Dana Desa (Studi Kasus Desa Bengkel Kecamatan Busungbiu, Kabupaten Buleleng) dimana dalam pelaporan Alokasi Dana Desa mengalami permasalahan keterlambatan pelaporan, sedangkan dalam penelitian ini untuk Alokasi Dana Desa di Desa Tellumpanuae tidak ada masalah mengenai pelaporan Alokasi Dana Desa. Menurut keterangan Sekretaris Desa Tellumpanuae, untuk pelaporan Alokasi Dana Desa tidak ada masalah karena sudah sesuai dengan peraturan yang ada dimana untuk pelaporannya tidak pernah mengalami keterlambatan.

Tujuan utama penelitian ini adalah Peneliti ingin mengkaji lebih dalam tentang pengelolaan Alokasi Dana Desa khusus di desa Tellumpanuae. Alasan peneliti melakukan penelitian di Desa Tellumpanuae yaitu sesuai dengan permasalahan yang ditemui peneliti mengenai Akuntabilitas dan Transparansi pengelolaan Alokasi Dana Desa yang perlu menjadi perhatian. Oleh karena itu diperlukan sentuhan pengetahuan dan pelatihan untuk memberikan gambaran kepada pemerintah desa dan masyarakat akan pentingnya akuntabilitas dan transparansi dalam pengelolaan Alokasi Dana Desa, sehingga akan berdampak pada peningkatan kualitas kerja perangkat desa dalam memberikan transparansi dan akuntabilitas kepada masyarakat dan dampak bagi masyarakat adalah masyarakat mengetahui program apa saja yang didanai oleh Alokasi Dana Desa sehingga masyarakat lebih mudah dalam mengawasi pelaksanaan kegiatan pembangunan desa apabila terjadi penyimpangan dan kendala-kendala di desa.

\section{METODE}

Jenis penelitian dalam penelitian ini adalah penelitian kualitatif dengan pendekatan analisis deskriptif. Menurut Sugiyono (2011), 
penelitian kualitatif adalah penelitian yang memanfaatkan wawancara terbuka untuk menelaah dan memahami sikap, pandangan, perasaan, dan perilaku individu atau sekelompok orang. Penelitian kualitatif dengan pendekatan analisis deskriptif menggunakan kata-kata tertulis atau lisan dari orang-orang dan pelaku yang diamati. Pendekatan ini diarahkan pada latar dan individu secara holistik (utuh). Metode kualitatif dapat diartikan sebagai metode yang digunakan untuk meneliti sebuah kondisi yang alamiah dimana peneliti adalah sebagai instrument kunci.

Lokasi penelitian ini adalah Desa Tellumpanuae, Kecamatan Mallawa, Kabupaten Maros, Provinsi Sulawesi Selatan. Penetapan informan dalam penelitian ini berdasarkan anggapan bahwa informan dapat memberikan informasi yang diinginkan penelitian sesuai dengan permasalahan penelitian. Informan dalam penelitian ini adalah Kepala Desa, Sekretaris Desa, Bendahara Desa, Tokoh Pemuda yang tergabung dalam organisasi pemuda karang taruna desa Tellumpanuae, Tokoh Masyarakat yang tergabung dalam Badan Permusyawaratan Desa (BPD), dan kepala seksi pembangunan yang kompeten dalam pengelolaan ADD dengan tujuan untuk mengetahui transparansi dan akuntabilitas pengelolaan ADD (Alokasi Dana Desa) yang diterapkan di Desa Tellumpanuae, Kecamatan Mallawa, Kabupaten Maros.

Jenis data yang dalam penelitian ini terdiri dari dua jenis, yaitu data primer dan data sekunder. Data primer diperoleh dari hasil wawancara kepada pihak desa mengenai akuntabilitas dan transaparansi terhadap pelaksanaan teknis alokasi dana desa di desa Tellumpanuae. Data sekunder berupa dokumen petunjuk pelaksanaan alokasi dana desa seperti Rencana Pembangunan Jangka Menengah (RPJM) desa, Rencana Kerja Pemerintah (RKP) desa, Laporan Pertanggungjawaban atau Laporan Realisasi ADD Tahun 2020.

Teknik pengumpulan data yang digunakan dalam penelitian ini adalah dengan menggunakan teknik dokumentasi dan teknik wawancara. Teknik Dokumentasi adalah data yang diperoleh dari catatan-catatan yang dimiliki pemerintah Desa. Teknik ini dilaksanakan dengan membuat copy atau pencatatan dari arsip resmi atau asli pemerintah desa. Dokumen yang diperlukan berupa arsip program perencanaan atau RKPDes (Rencana Kerja Pemerintah Desa), RPJMD (Rencana Pembangunan Jangka Menengah Desa), dan dokumen lain yang relevan. Teknik wawancara adalah teknik pengambilan data dengan cara menanyakan sesuatu kepada seseorang responden, caranya adalah dengan bercakapcakap secara tatap muka. Pada penelitian ini teknik wawancara dilengkapi dengan pedoman wawancara yang sangat umum, serta mencantumkan isu-isu yang harus diliput tanpa menentukan urutan pertanyaan, bahkan mungkin tidak terbentuk pertanyaan yang eksplisit. Wawancara dilakukan dengan tanya jawab, dengan cara ini memungkinkan perolehan data langsung dari Objek Penelitian.

Dalam penelitian ini, teknik analisis data yang akan dilakukan adalah teknik analisis deskriptif kualitatif dengan menggunakan model 
Miles dan Huberman (2011). Dimana hal ini dilakukan secara interaktif dan berlangsung terus menerus sampai tuntas. Ukuran ketuntasan data ditandai dengan tidak diperolehnya lagi data atau informasi baru. Prosedur analisis data terbagi ke dalam tiga aktivitas, antara lain: data reduction, data display, dan conclusion drawing/verification.

Data Reduction merupakan data yang diperoleh dari lapangan, bisa memiliki jumlah yang banyak karena pengulangan kata atau kalimat yang sering terjadi, banyaknya penggunaan kata yang tidak penting, sehingga kita harus teliti memilihnya. Untuk itu perlu dilakukan analisis data melalui reduksi data. Mereduksi data berarti merangkum, memilih hal-hal yang pokok dan memfokuskan pada hal-hal yang penting, mencari tema dan polanya. Dengan demikian data yang telah direduksi akan memberikan gambaran yang lebih jelas dan mempermudah peneliti untuk melakukan pengumpulan data selanjutnya. Dalam penelitian ini, hal yang paling awal dilakukan peneliti adalah mengumpulkan data primer melalui wawancara dan data sekunder yang terkait dengan pengelolaan yang mencakup lima proses yaitu perencanaan, pelaksanaan, penatausahaan, pelaporan, dan pertanggungjawaban. Setelah data didapatkan, peneliti melakukan reduksi data. Reduksi data dilakukan dengan menggolongkan semua dokumendokumen yang terkait penatausahaan, pelaporan, dan pertanggungjawaban.

Data Display atau penyajian data. Setelah data direduksi maka langkah selanjutnya adalah mendisplaykan data. Dalam penelitian kualitatif, penyajian data yang bisa disajikan dalam uraian singkat, hubungan antara kategori dan sejenisnya. Yang paling sering digunakan untuk penyajian data kualitatif adalah dengan teks yang bersifat naratif. Dengan mendisplaykan data maka akan memudahkan untuk memahami apa yang terjadi, merencanakan kerja selanjutnya berdasarkan apa yang dipahami tersebut. Pada proses ini akan dilakukan penyajian dari hasil wawancara yang dituangkan dalam bentuk teks. Selanjutnya dokumendokumen yang telah diperoleh, dievaluasi dengan menggunakan indikator yang sesuai dengan Permendagri 113 Tahun 2014.

Conclusion drawing/verification atau penarikan kesimpulan dan verifikasi merupakan langkah ketiga setelah dua langkah sebelumnya. Kesimpulan awal adalah masih bersifat sementara dan akan berubah bila tidak ditemukan bukti-bukti yang kuat yang mendukung pada tahap pengumpulan data berikutnya. Tetapi apabila kesimpulannya pada tahap awal didukung oleh bukti-bukti yang valid maka kesimpulan yang dikemukan merupakan kesimpulan yang kredibel. Dalam penelitian ini penarikan kesimpulan dikaitkan dengan pedoman undang-undang pengelolaan ADD agar bias dikatakan akuntabel dan transparan.

\section{HASIL}

\section{Akuntabilitas Pengelolaan Dana Desa di Desa Tellumpanuae}

Akuntabilitas adalah suatu bentuk pertanggungjawaban oleh pihak yang diberi kepercayaan oleh masyarakat/individu dimana nantinya 
terdapat keberhasilan atau kegagalan di dalam pelaksanaan tugasnya tersebut dalam pencapaian tujuan yang telah ditetapkan. Pertanggungjawaban tersebut berkaitan langsung dengan aktivitas birokrasi dalam memberikan pelayanan sebagai kontra prestasi atas hakhak yang telah dipungut langsung maupun tidak langsung dari masyarakat. Pertanggungjawaban perlu dilakukan melalui media yang selanjutnya dapat dikomunikasikan baik kepada pihak internal maupun kepada pihak eksternal (publik) secara periodik maupun secara tak terduga sebagai suatu kewajiban hukum bukan karena sukarela.

Teori pengelolaan keuangan desa menurut Herlianto (2017) dimulai dari perencanaan, kemudian diikuti dengan penganggaran, pelaksanaan, penatausahaan, pelaporan, pertanggungjawaban dan diakhiri dengan pengawasan. Tahapan pengelolaan keuangan desa tersebut dituangkan kedalam bagan oleh penulis sebagaimana dapat dilihat pada gambar 1 berikut:

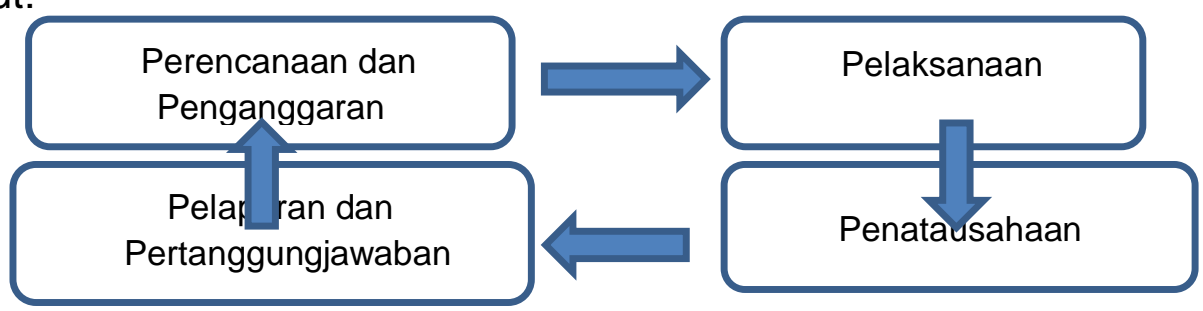

Gambar 1. Tahapan Pengelolaan Keuangan Desa

Sistem akuntabilitas dalam pengelolaan dana Alokasi Dana Desa dimulai dari tahap perencanaan, pelaksanaan sampai pertanggungjawaban sudah ditentukaan didalam pada Peraturan Daerah Kabupaten Maros Nomor 1 Tahun 2006 tentang Pengelolaan Keuangan Desa. Seluruh kegiatan yang didanai dari dana desa direncanakan, dilaksanakan, dan dievaluasi secara terbuka dengan melibatkan seluruh unsur masyarakat desa, dimana seluruh kegiatan harus dapat dipertanggungjawabkan.

Penggunaan dana desa yang diterima setiap desa digunakan untuk dua komponen yakni sebesar 70\% digunakan untuk pemberdayaan masyarakat dan pembangunan desa, dan sebesar $30 \%$ digunakan untuk membiayai operasional pemerintahan desa dan Badan Permusyawaratan Desa.

Dari hasil penelitian yang telah dilakukan, untuk aspek penatausahaan dana desa Tellumpanuae telah berpedoman pada Permendagri Nomor 113 Tahun 2014. Hal tersebut terlihat dengan adanya Peraturan Desa mengenai Anggaran Pendapatan dan Belanja Desa (APBDes) yang telah dibahas dan disepakati bersama Badan Permusyawaratan Desa (BPD). Penatausahaan yang dilakukan oleh desa Tellumpanuae melalui pencatatan oleh Bendahara Desa meliputi buku kas umum, buku kas pembantu pajak dan buku bank guna membantu pencatatannya. 
Dalam penatausahaan pengelolaan dana desa di desa Tellumpanuae sesuai dengan hasil wawancara yang diperoleh dari Kepala Desa Tellumpanuae, mengungkapkan bahwa "Untuk penatausahaan desa Tellumpanuae kita sudah mengacu pada permendagri 113, mulai dari pencatatannya hingga pelaporannya". Lebih lanjut di kemukakan oleh Sekdes bahwa "Desa Tellumpanuae juga telah menggunakan aplikasi SIMDA Desa walaupun versinya masih versi lama yaitu tahun 2015, setidaknya kami sudah memanfaatkan teknologi informasi yang ada".

Dari hasil penelitian yang telah diperoleh dapat di jabarkan indikator kesesuaian akuntabilitas penatausahaan menurut Permendagri nomor 113 Tahun 2014 sebagai berikut:

Tabel 1. Indikator Kesesuaian Akuntabilitas Penatausahaan Menurut Permendagri Nomor 113 Tahun 2014

\begin{tabular}{cllc}
\hline No. & \multicolumn{1}{c}{ Indikator } & \multicolumn{1}{c}{ Hasil Wawancara } & Keterangan \\
\hline 1. & $\begin{array}{l}\text { Penatausahaan dilakukan oleh } \\
\text { Bendahara Desa }\end{array}$ & $\begin{array}{l}\text { Penatausahaan di desa } \\
\text { Tellumpanuae dilakukan oleh } \\
\text { Bendahara Desa }\end{array}$ & Sesuai \\
2. & $\begin{array}{l}\text { Bendahara Desa wajib melakukan } \\
\text { pencatatan setiap penerimaan } \\
\text { dan pengeluaran serta melakukan } \\
\text { tutup buku setiap akhir bulan } \\
\text { secara tertib }\end{array}$ & $\begin{array}{l}\text { Setiap penerimaan dan } \\
\text { pengeluaran kas, Bendahara } \\
\text { selalu mencatat dan } \\
\text { melakukan tutup buku setiap } \\
\text { bulan secara tertib }\end{array}$ & Sesuai \\
$\begin{array}{lll}\text { Bendahara Desa wajib } \\
\text { mempertanggungjawabkan dana } \\
\text { melalui laporan } \\
\text { pertanggungjawaban }\end{array}$ & $\begin{array}{l}\text { Laporan pertanggungjawaban } \\
\text { setiap bulan disampaikan } \\
\text { melalui laporan } \\
\text { pertanggungjawaban bulanan } \\
\text { oleh Bendahara }\end{array}$ & Sesuai \\
& $\begin{array}{l}\text { Laporan pertanggungjawaban } \\
\text { disampaikan setiap bulan kepada } \\
\begin{array}{l}\text { Kepala Desa dan paling lambat } \\
\text { tanggal 10 bulan berikutnya }\end{array}\end{array}$ & $\begin{array}{l}\text { Bendahara menyampaikan } \\
\text { laporan pertanggungjawaban } \\
\text { setiap bulan kepada Kepala } \\
\text { Desa }\end{array}$ & Sesuai \\
\hline
\end{tabular}

Selanjutnya akuntabilitas pengelolaan dana desa dari aspek pelaporan pengelolaan dana desa di desa Tellumpanuae, dimana hal ini secara teknis di atur dalam Permendagri nomor 113 Tahun 2014 pasal 37 dimana Kepala Desa menyampaikan laporan realisasi APBDes kepada Bupati atau wakil Bupati berupa laporan semester pertama dan laporan semester akhir. Laporan realisasi semester pertama APBDes paling lambat disampaikan pada akhir bulan Juli tahun berjalan dan sementara laporan semester akhir tahun paling lambat disampaikan bulan januari tahun berikutnya.

Akuntabilitas berdasarkan aspek pelaporan pengelolaan dana desa di desa Tellumpanuae untuk semester pertama telah disampaikan pada bulan Juli 2020 sesuai dengan aturan, sedangkan untuk pelaporan semester akhir tahun masih dalam tahap pengerjaan melihat dengan dibuatnya penelitian ini masih dalam tahun periode berjalan. Hal ini sesuai 
dengan hasil wawancara dengan Pemerintah Desa sebagai berikut: "Laporan realisasi untuk semester satu sudah dilaporkan oleh Kepala Desa ke Bupati melalui Camat pada bulan Juli lalu. Sedangkan untuk laporan realisasi untuk semester dua sedang dalam proses pengerjaan karena masih berjalan, biasanya Januari kami sudah melaporkan".

Dari hasil penelitian yang telah diperoleh dapat di jabarkan indikator kesesuaian akuntabilitas pelaporan menurut Permendagri nomor 113 Tahun 2014 sebagai berikut:

Tabel 2. Indikator Kesesuaian Akuntabilitas Pelaporan Menurut Permendagri Nomor 113 Tahun 2014

\begin{tabular}{cllc}
\hline No. & \multicolumn{1}{c}{ Indikator } & \multicolumn{1}{c}{ Hasil Wawancara } & Keterangan \\
\hline 1. & $\begin{array}{l}\text { Kepala Desa menyampaikan } \\
\text { laporan realisasi pelaksanaan } \\
\text { APBDesa kepada Bupati/Walikota } \\
\text { berupa laporan semester pertama } \\
\text { dan laporan semester akhir tahun }\end{array}$ & $\begin{array}{l}\text { Laporan semester pertama } \\
\text { dilaporkan oleh Kepala Desa } \\
\text { kepada Bupati melalui Camat }\end{array}$ & Sesuai \\
2. & $\begin{array}{l}\text { Laporan semester pertama } \\
\text { berupa laporan realisasi APBDesa }\end{array}$ & $\begin{array}{l}\text { Laporan realisasi semester } \\
\text { pertama berupa APBDesa }\end{array}$ & Sesuai \\
3. $\quad \begin{array}{l}\text { Laporan realisasi pelaksanaan } \\
\text { APBDesa semester pertama } \\
\text { disampaikan paling lambat pada } \\
\text { akhir bulan Juli tahun berjalan }\end{array}$ & $\begin{array}{l}\text { Laporan semester pertama } \\
\text { dilaporkan oleh Kepala Desa } \\
\text { kepada Bupati Melalui Camat } \\
\text { pada bulan Juli }\end{array}$ & Sesuai \\
& $\begin{array}{l}\text { Laporan semester akhir tahun } \\
\text { disampaikan paling lambat pada } \\
\text { akhir bulan Januari tahun } \\
\text { berikutnya }\end{array}$ & $\begin{array}{l}\text { Laporan semester akhir tahun } \\
\text { belum disampaikan karena } \\
\text { masih pada tahun berjalan }\end{array}$ & Belum \\
\hline
\end{tabular}

Selanjutnya akuntabilitas pengelolaan dana desa dari aspek pertanggungjawaban pengelolaan dana desa di desa Tellumpanuae. Sebagaimana disebutkan dalam Permendagri nomor 113 Tahun 2014 pasal 38 bahwa Kepala Desa menyampaikan kepada Bupati/Walikota melalui Camat setiap akhir tahun anggaran berupa laporan pertanggungjawaban realisasi pelaksanaan APBDesa yang terdiri dari pendapatan, belanja, dan pembiayaan yang sudah ditetapkan dalam peraturan desa yang dilampiri dengan beberapa berkas diantaranya sebagai berikut:

a. Format laporan pertanggungjawaban realisasi pelaksanaan APBDesa tahun anggaran berkenaan.

b. Format laporan kekayaan milik desa pada akhir bulan Desember tahun anggaran berkenaan.

c. Format laporan program pemerintah dan pemerintah daerah yang masuk ke desa.

Dari hasil penelitian yang telah diperoleh dapat di jabarkan indikator kesesuaian akuntabilitas pertanggungjawaban menurut Permendagri nomor 113 Tahun 2014 sebagai berikut:

Tabel 3. Indikator Kesesuaian Akuntabilitas Pertanggungjawaban 


\section{Menurut Permendagri Nomor 113 Tahun 2014}

\begin{tabular}{|c|c|c|c|}
\hline No. & Indikator & Hasil Wawancara & Keterangan \\
\hline 1. & $\begin{array}{l}\text { Kepala Desa menyampaikan } \\
\text { laporan pertanggungjawaban } \\
\text { realisasi pelaksanaan APBDesa } \\
\text { kepada Bupati/Walikota setiap } \\
\text { akhir tahun anggaran }\end{array}$ & $\begin{array}{l}\text { Kepala Desa belum } \\
\text { menyampaikan laporan } \\
\text { pertanggungjawaban realisasi } \\
\text { pelaksanaan APBDesa } \\
\text { kepada Bupati/Walikota di } \\
\text { akhir tahun anggaran karena } \\
\text { masih dalam proses kegiatan } \\
\text { tahun berkenaan }\end{array}$ & $\begin{array}{l}\text { Belum } \\
\text { Terjadi }\end{array}$ \\
\hline 2. & $\begin{array}{l}\text { Laporan pertanggungjawaban } \\
\text { realisasi pelaksanaan APBDesa } \\
\text { terdiri dari pendapatan, belanja } \\
\text { dan pembiayaan }\end{array}$ & $\begin{array}{l}\text { Laporan pertanggungjawaban } \\
\text { realisasi pelaksanaan } \\
\text { APBDesa terdiri dari } \\
\text { pendapatan, belanja dan } \\
\text { pembiayaan }\end{array}$ & $\begin{array}{l}\text { Belum } \\
\text { Terjadi }\end{array}$ \\
\hline 3. & $\begin{array}{l}\text { Laporan pertanggungjawaban } \\
\text { realisasi pelaksanaan APBDesa } \\
\text { ditetapkan dengan Peraturan } \\
\text { Desa }\end{array}$ & $\begin{array}{l}\text { Laporan pertanggungjawaban } \\
\text { realisasi pelaksanaan } \\
\text { APBDesa ditetapkan dengan } \\
\text { Peraturan Desa }\end{array}$ & Sesuai \\
\hline
\end{tabular}

\section{Transparansi Pengelolaan Dana Desa di Desa Tellumpanuae}

Transparansi adalah prinsip keterbukaan yang memungkinkan masyarakat untuk mengetahui dan mendapatkan akses informasi seluasluasnya tentang keuangan daerah. Menurut Andrianto (2007) menyatakan bahwa transparansi dibangun atas dasar informasi yang bebas dimana seluruh proses pemerintahan, lembaga-lembaga, dan informasi perlu dapat diakses oleh pihak-pihak yang berkepentingan dan informasi yang tersedia harus memadai agar dapat dimengerti dan dipantau.

Prinsip transparansi diwujudkan dimana dalam perencanaan ADD melibatkan perangkat desa, BPD (Badan Permusyawaratan Desa) sebagai wakil dari masyarakat, LPMD (Lembaga Pemerdayaan Masyarakat) sebagai mitra dalam pengerjaan kegiatan fisik dan tokoh masyarakat dalam pengambilan keputusan program kegiatan yang akan dilakukan dengan memberikan papan informasi yang di pampang di Kantor Desa Tellumpanuae agar masyarakat mengetahui program apa saja yang didanai oleh Dana Desa, sehingga masyarakat lebih mudah dalam mengawasi pelaksanaan kegiatan pembangunan desa apabila terjadi penyimpangan dan kendala-kendala di desa. Prinsip transparansi dapat didukung dengan adanya respon positif dari masyarakat agar dapat terwujud prinsip good governance didalam Pemerintahan Desa.

Sesuai pemaparan hasil wawancara dengan Kepala Desa Tellumpanuae sebagai berikut: "Dalam upaya mewujudkan prinsip transparansi pengelolaan $A D D$, proses perencanaan pengelolaan alokasi dana desa diawali dengan Musyawarah Perencanaan Pembangunan Desa (Musrenbangdes) untuk merumuskan tentang RAPBDesa yang akan diajukan kepada Bupati melalui Camat. Mesrenbangdes ini dihadiri BPD, LPM, Tokoh Adat, Kader Pemerdayaan Desa, Ketua PKK dan dipantau 
tim dari kecamatan. Disamping itu, ada pemasangan papan informasi di kantor desa, hal ini dilakukan untuk memberikan informasi kepada masyarakat mengenai penggunaan dana desa dan program apa saja yang telah di realisasikan. Selanjutnya untuk informasi yang bisa diakses melalui internet juga sudah bisa terlaksana tetapi hanya bisa diakses di tempat tertentu misalnya di kantor desa ini karena keterbatasan jaringan internet didesa ini".

Berikut pula hasil wawancara dari salah satu masyarakat desa Tellumpanuae sebagai berikut: "Alhamdulillah sekarang jalannya sudah mulai dipaving semua, kita bisa bilang kepada perangkat desa apa keinginan kita keinginan masyarakat (masalah dilapangan). Kami juga bisa tau berapa jumlahnya uang tersebut yang digunakan untuk pavingpaving jalanan melalui papan informasi yang dipasang dihalaman kantor desa".

Dari hasil penelitian yang telah diperoleh dapat di jabarkan indikator kesesuaian transparansi pengelolaan dana desa menurut Permendagri nomor 113 Tahun 2014 sebagai berikut:

Tabel 4. Indikator Kesesuaian Transparansi Pengelolaan Dana Desa Menurut Permendagri Nomor 113 Tahun 2014

\begin{tabular}{|c|c|c|c|}
\hline No. & Indikator & Hasil Wawancara & Keterangan \\
\hline 1. & $\begin{array}{l}\text { Indikator pencatatan kas masuk } \\
\text { maupun kas keluar dapat diakses } \\
\text { dengan mudah oleh masyarakat, } \\
\text { serta ada papan pengumuman } \\
\text { mengenai kegiatan yang sedang } \\
\text { dijalankan. }\end{array}$ & $\begin{array}{l}\text { Pencatatan kas masuk dan } \\
\text { kas keluar bisa diakses oleh } \\
\text { masyarakat, serta terdapat } \\
\text { papan pengumuman tentang } \\
\text { informasi dana yang } \\
\text { digunakan untuk menjalankan } \\
\text { sebuah kegiatan }\end{array}$ & Sesuai \\
\hline 2. & $\begin{array}{l}\text { Laporan realisasi dan laporan } \\
\text { pertanggungjawaban realisasi } \\
\text { pelaksanaan APBDesa } \\
\text { diinformasikan kepada } \\
\text { masyarakat secara tertulis dan } \\
\text { dengan media informasi yang } \\
\text { mudah diakses oleh masyarakat. }\end{array}$ & $\begin{array}{l}\text { Laporan realisasi dan laporan } \\
\text { pertanggungjawaban realisasi } \\
\text { pelaksanaan APBDesa } \\
\text { diinformasikan kepada } \\
\text { masyarakat secara tertulis } \\
\text { melalui papan informasi dan } \\
\text { bisa diakses oleh masyarakat }\end{array}$ & Sesuai \\
\hline 3. & $\begin{array}{l}\text { Laporan realisasi dan laporan } \\
\text { pertanggungjawaban realisasi } \\
\text { pelaksanaan dana desa } \\
\text { disampaikan kepada } \\
\text { Bupati/Walikota melalui Camat. }\end{array}$ & $\begin{array}{l}\text { Tahun-tahun sebelumnya } \\
\text { sesuai informasi dari Sekdes } \\
\text { bahwa Laporan realisasi dan } \\
\text { laporan pertanggungjawaban } \\
\text { realisasi pelaksanaan dana } \\
\text { desa disampaikan kepada } \\
\text { Bupati/Walikota melalui Camat } \\
\text { oleh Kepala Desa, namun } \\
\text { sampai saat ini laporan } \\
\text { pertanggungjawaban } \\
\text { pengelolaan dana desa masih } \\
\text { berjalan. }\end{array}$ & $\begin{array}{l}\text { Belum } \\
\text { Terjadi }\end{array}$ \\
\hline
\end{tabular}




\section{Akuntabilitas dan Transparansi Pengelolaan Dana Desa di Desa Tellumpanuae}

Akuntabilitas tahap penatausahaan, pelaporan dan pertanggungjawaban pengelolaan dana desa pada desa Tellumpanuae Kabupaten Maros pada penerapannya sudah berpedoman pada Permendagri Nomor 113 Tahun 2014. Dalam penatausahaannya, harus menggunakan sistem yang telah memanfaatkan Teknologi Informasi (TI) yaitu dengan menggunakan aplikasi yang telah dikembangkan oleh BPKP, yaitu Aplikasi Sistem Tata Kelola Keuangan Desa atau SIMDA Desa (Oktaresa, 2015). Pada desa Tellumpanuae, juga telah menggunakan aplikasi SIMDA Desa. Namun sayangnya pemerintah desa Tellumpanuae masih menggunakan versi lama yaitu versi tahun 2015.

Dalam pertanggungjawaban Pemerintahan Desa terhadap dana desa dibuatlah Laporan Realisasi, Laporan Realisasi adalah bentuk pertanggungjawaban Pemerintahan Desa terhadap pengelolaan Alokasi Dana Desa yang dilaporkan dua kali dalam setahun atau setiap semester dalam setahun. Laporan Pertanggungjawaban Realisasi Pelaksanaan APBDesa adalah pertanggungjawaban Pemerintahan Desa terhadap pengelolaan dana desa secara terperinci yang ditunjukan kepada pemberi amanah yang tentunya agar dapat menjadi lebih transparan dan akuntabel mengenai segala aktifitas yang telah dilaksanakan terhadap dana tersebut.

Transparansi merupakan hak seluruh lapisan masyarakat terhadap kebebasan mengetahui kegiatan pembangunan yang berasal dari dana Pemerintah yang tujuan utamanya memang untuk pemberdayaan masyarakat seperti dana ADD. Transparansi mengukur tingkat keamanahan pihak pengelola dalam menjalankan kegiatan pembangunan. Hal ini sesuai dengan Firman Allah SWT dalam Al-Qur'an Surah An-Nisa ayat 58 , yaitu:

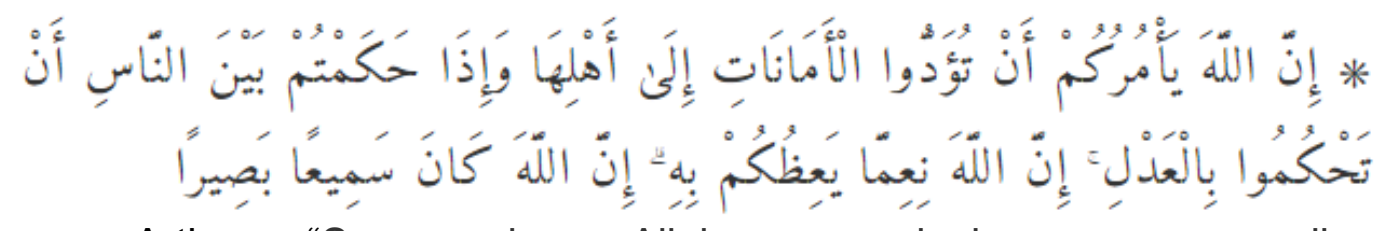

Artinya: "Sesungguhnya Allah menyuruh kamu menyampaikan amanat kepada yang berhak menerimanya, dan (menyuruh kamu) apabila menetapkan hukum di antara manusia supaya kamu menetapkan dengan adil. Sesungguhnya Allah memberi pengajaran yang sebaik-baiknya kepadamu. Sesungguhnya Allah adalah Maha Mendengar lagi Maha Melihat".

Transparansi pengelolaan dana desa pada desa Tellumpanuae untuk seluruh penerapannya sudah sesuai dengan Permendagri Nomor 113 Tahun 2014, yaitu adanya kegiatan pencatatan kas masuk maupun keluar yang dapat diakses oleh masyarakat serta ada papan informasi mengenai kegiatan yang telah dijalankan beserta jumlah anggaran yang digunakan, adanya laporan realisasi dan laporan pertanggungjawaban 
realisasi pelaksanaan APBDesa diinformasikan kepada masyarakat secara tertulis dan dengan media informasi yang mudah diakses oleh masyarakat, serta laporan realisasi dan laporan pertanggungjawaban realisasi pelaksanaan ADD disampaikan kepada Bupati/Walikota melalui Camat.

Untuk menjamin adanya transparansi tidak lepas dari akuntabilitas dalam pengelolaan alokasi dana desa maka tentang transparansi ini diatur juga di dalam Pasal 40 Permendagri No. 113 Tahun 2014 Tentang Pengelolaan Keuangan Desa, dimana dikatakan laporan realisasi dan laporan pertanggungjawaban realisasi pelaksanaan APBDesa diinformasikan kepada masyarakat secara tertulis dan dengan media informasi yang mudah diakses oleh masyarakat. Namun desa masih perlu bimbingan terkait pertanggungjawaban dana desa, agar bisa selalu tepat waktu dalam penyampaian pertanggungjawaban dana desa.

Hasil penelitian ini sejalan dengan penelitian yang dilakukan oleh Sartika, dkk (2018) yang meneliti tentang Akuntabilitas dan Transparansi Alokasi Dana Desa Pada Nagari Labuah Gunuang. Hasil penelitian menunjukkan bahwa perencanaan dan pelaksanaan kegiatan ADD sudah memperlihatkan pengelolaan yang akuntabel dan berdasarkan dalam laporan pertanggungjawaban dilihat secara hasil fisik juga sudah menunjukkan pelaksanaan yang akuntabel, namun masih perlu adanya pelatihan dan bimbingan teknis kepada aparatur nagari khususnya bendahara agar bisa menyusun laporan kekayaan milik Nagari.

\section{Dampak Jika Tidak Adanya Akuntabilitas dan Transparansi pengelolaan Dana Desa Bagi Desa Tellumpanuae}

Pengelolaan dan pelaksanaan kegiatan Pemerintahan Desa, perlu adanya suatu aspek tata Pemerintahan yang baik (Good Governance). Salah satu unsur utama dari Good Governance adalah Akuntabilitas sebagai bentuk tanggungjawab pelaksanaan misi organisasi dalam mencapai tujuan yang telah ditetapkan melalui media pertanggungjawaban yang dilaksanakan secara periodik. Akuntabilitas dan Transparansi merupakan hal yang penting dalam menjalankan pengelolaan Alokasi Dana Desa di Desa Tellumpanuae agar tata pengelolaan pemerintah di desa dapat berjalan dengan baik.

\section{Implikasi Akuntabilitas dan Transparansi Terhadap Perkembangan Konsep/Keilmuan}

Implementasi penelitian ini lebih kepada teori agensi, merupakan konsep yang menjelaskan hubungan kontraktual antara principals dan agents. Pihak principals adalah pihak yang memberikan mandat kepada pihak lain, yaitu agent, untuk melakukan semua kegiatan atas nama principals dalam kapasitasnya sebagai pengambil keputusan, (Jensen dan Smith, 1984).Principal merupakan rakyat dan agen adalah pemerintah dalam hal ini adalah kepala desa dan aparat desa lainnya. Dari hasil penelitian menunjukkan bahwa Pemerintah desa Tellumpanuae telah 
mengupayakan implementasi teori agensi yang mana pemerintah desa telah melakukan tanggung jawab berupa penyampaian kinerja melalui berbagai media informasi.

\section{Keterbatasan Penelitian}

Penelitian ini hanya membahas pengelolaan teknis keuangan desa berdasarkan Permendagri nomor 113 Tahun 2014 yaitu mengenai penatausahaan, pelaporan, dan pertanggungjawaban. Kesulitan mendapatkan akses terhadap kinerja dan pelaporan membuat peneliti hanya mendapatkan hasil penelitian ini yang menyajikan perbandingan kesesuaian undang-undang dengan aplikasi dilapangan, sehingga keterbatasan dalam penelitian ini adalah tidak membahas secara mendalam setiap komponen pengelolaan keuangan desa dan tidak pula membahas nominal keuangan desa.

\section{KESIMPULAN}

Penelitian yang telah dilakukan dapat ditarik kesimpulan mengenai akuntanbilitas dan transparansi pengelolaan Dana Desa di Desa Tellumpanuae sebagai berikut:

1. Akuntabilitas penatausahaan, pelaporan dan pertanggungjawaban pengelolaan dana desa di desa Tellumpanuae sudah menggunakan format sesuai dengan Permendagri nomor 113 Tahun 2014, sehingga dalam proses penatausahaan, pelaporan dan pertanggungjawaban pengelolaan dana desa di desa Tellumpanuae dikatakan Akuntabel.

2. Transparansi untuk desa Tellumpanuae sudah sesuai dengan Permendagri nomor 113 Tahun 2014 yakni adanya musrenbangdes setiap awal tahun untuk mendengarkan ide atau keluhan warga, dan adanya papan informasi tentang program dana desa dan anggarannya, sehingga dalam hal ini desa Tellumpanuae dikatakan Transparan.

\section{DAFTAR PUSTAKA}

Andrianto, Nico. (2007). Transparansi dan Akuntabilitas Publik Melalui eGovernment. Malang: Bayumedia Publishing.

Astuty, Elgia dan Fanida, Eva H. (2013). Akuntabilitas Pemerintah Desa dalam Pengelolaan Anggaran Pendapatan dan Belanja Desa (APBDES) (Studi pada Alokasi Dana Desa Tahun Anggaran 2011 di Desa Sareng Kecamatan Geger Kabupaten Madiun). 1-11.

Dwiyanto, Agus (2006). Mewujudkan Good Governance Melalui Pelayanan Publik. 20-35.

Herlianto, D. (2017). Manajemen Keuangn Desa. Yogyakarta: Gosyen Publishing

Ismail, M. dkk. (2016). Sistem Akuntansi Pengelolaan Dana Desa. 19 (2), 1-20.

Jensen, M. C. Dan Clifford, W. S. (1984). The Theory of Corporate Finance: A Historical Overview. New York: McGraw-Hill Inc. pp. 220. 
Oktaresa, B. (2015). Analisis Hubungan Pengalaman, Pengetahuan Mendeteksi Kecurangan, dan Skeptisme Profesional dengan Kemampuan Pendeteksian Kecurangan Pada Perwakilan BPKP Provinsi Riau. 40-57.

Peraturan Daerah Kabupaten Maros Nomor 01 Tahun 2006 Tentang Alokasi Dana Desa (ADD) Kabupaten Maros.

Peraturan Pemerintah Nomor 47 Tahun 2015 Tentang Perubahan Atas Perubahan Pemerintah Nomor 43 Tahun 2014 Tentang Peraturan Pelaksanaan UndangUndang Nomor 6 Tahun 2014 Tentang Desa.

Putriyanti, Aprisiami (2012). Penerapan Otonomi Desa Dalam Menguatkan Akuntabilitas Pemerintah Desa Dan Pemberdayaan Masyarakat Di Desa Aglik, Kecamatan Grabag, Kabupaten Puwerjo. Universitas Negeri Yogyakarta.

Ross, S. A. (1973). The Economic Theory of Agency: The Principal's Problem. Papers and Proceedings of the Eighty-fifth Annual Meeting of the American Economic Association. 63 (2), 134-139.

Sartika, dkk. (2018). Akuntabilitas dan Transparansi Alokasi Dana Desa (ADD) Pada Nagari Labuah Gunuang. 20 (1) : 26-40.

Sugiyono. (2011). Memahami Penelitian Kuantitatif. Bandung: Alfabeta.

Sulistyani. (2004). Kemitraan dan Model-Model Pemberdayaan .Yogyakarta. Graha IImu.

Wiradarma. (2017). Analisis Transparansi dan Akuntabilitas Pelaporan Alokasi Dana Desa (Studi Kasus Desa Bengkel, Kec. Busungbiu,Kab.Buleleng). 7 (1): 40-55. 